\title{
ЛОГІКА ПІЗНАННЯ («ГНОСЕОЛОГІЯ») ЯК СКЛАДОВА ТВОРЧОГО МЕТОДУ
}

\section{Сергій Безклубенко}

доктор філософських наук, професор, почесний академік Національної академії мистецтв України; e-mail: bezklub@knukim.edu.ua; ORCID: 0000-0002-8709-7129

Київський національний університет культури і мистецтв, Київ, Україна

\begin{abstract}
Анотація
Мета статті - з'ясування сутності поетики (або, що те саме, мистецького творчого методу). Методологія дослідження базується на принципі системності: автор дотримується концепції, згідно з якою мистецтво як творчий процес являє собою певну систему. Наукова новизна. Будучи формою суспільної свідомості, способом самовираження особи та засобом утвердження певних ідей, мистецтво є заразом одним із видів виробництва. Це виробництво специфічне (духовне), особливе з-поміж духовних (художнє) та все ж являє собою таке, якому притаманні всі його фундаментальні риси взагалі, у тому числі (1) організаційні, (2) економічні та (3) технологічні. Щодо (1): мистецтво як виробництво художніх цінностей у своєму історичному розвитку проходить ті ж стадії суспільної (колективної) організації праці, що й виробництво взагалі (у тому числі й матеріальних благ). А саме: кооперація (іконописні, взагалі малярські майстерні), мануфактура (театр), фабрика (кіно), індустрія (телебачення). Щодо (2) - деякі мистецтва (наприклад, кінематограф) являють собою самостійні галузі виробництва, притому вельми ефективні в економічному сенсі. Щодо (3) - технологія художнього виробництва, осмислена у своїй закономірності, визначає специфіку мистецтва з його практично-виробничого (ремісничого боку). Висновки. Виходячи з такого розуміння мистецтва (мистецького творчого процесу), сутність поетики, яка з формального боку має вигляд деякої сукупності (систему) певних принципів та правил, автор розглядає як логіку творчого процесу, у котрій своєрідними гранями постають (у різних видах мистецтва - різною мірою) гносеологічні, психологічні, ідеологічні та технологічні аспекти мистецького творчого процесу. У цій публікації проаналізовано саме гносеологічний аспект поетики (творчого методу).
\end{abstract}

Ключові слова: метод; творчість; мистецтво; технологія; гносеологія

\section{Аналіз літератури}

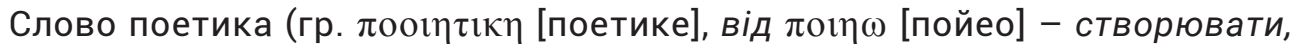
виготовляти, виробляти) - 1) у вузькому розумінні це сукупність принципів, правил, прийомів поетичної творчості (віршування) (кажуть: поетика Шевченка, пушкінська поетика тощо); 2) у загальному - система, принаймні сукупність принципів, правил та засобів і форм художньої творчості. У цьому значенні термін «поетика» своїм походженням завдячує Аристотелю, який саме так назвав своє дослідження мистецтва.

Мова в «Поетиці» Аристотеля йшла переважно про твори драматичні трагедію та комедію, але оскільки писали їх тоді віршованою ритмічною мовою, 
Вісник Київського національного університету культури і мистецтв.

Серія: Сценічне мистецтво

$2019 \cdot 2(1) \cdot c .27-41$

термін «поетика» тривалий час зберігав значення зводу правил віршування або поезії, як було названо один із родів художньої літератури. Такою, наприклад, $\epsilon$ (до речі, віршована) книга француза М. Буало «Поетичне мистецтво» (1674), в якій розповідається, зокрема, що таке елегія, ода, сонет, епіграма, балада, рондо, мадригал тощо і в чому їх особливості; а також книга професора КиєвоМогилянської академії М. Довгалевського «Поетика. Сад поетичний» (1736), в якій викладено успадковані від античних часів уявлення про суть і призначення поезії, техніку віршування та відповідні засоби: метафору, синекдоху, метонімію, антиномію, ономатопею та інші види тропів.

Водночас з певного часу терміном «поетика» дещо метафорично почали називати притаманний окремому письменникові, поетові стиль, творчий метод, схильність до певних художніх засобів зображення та самовираження. Так, надзвичайно цікава та повчальна книга М. Бахтіна з теорії художньої творчості називається «Проблеми поетики Достоєвського» (1964). За аналогією поетикою стали згодом іменувати і специфічні правила творчості в тій чи іншій галузі мистецтва. «Поетика кіномистецтва» - таку назву має, зокрема, книга Є. Добіна, видана у 1961 р., та ін. Усі згадані та не згадані тут автори розглядають поетику з суто формального боку: як сукупність (або систему) правил компонування твору.

Явище, означуване словом поетика, дедалі частіше стали називати методом творчості (Максим Горький, В. Шкловський), також обмежуючись при цьому формальним описанням його як сукупності певних прийомів і не вдаючись до спроб з'ясування, що ж він являє собою за своєю глибинною сутністю. Так, наприклад, академік І. Дзюба свого часу задекларував: «Метод - це насамперед розуміння», - і навіть виніс ці слова у заголовок своєї вельми розлогої статті (Shevchenko, Shevchenko, and Salakhova, 2017). Оскільки це речення неповне, незакінчене і думка видається недостатньо ясною, у читача виникає питання: що власне має на увазі автор (розуміння... чого саме?). Та відповіді на це питання годі шукати в згаданій, як і в інших, публікації знаного літератора. Відтак з'являється здогад: йдеться саме про розуміння того, що ж по суті являє собою метод. Ретельне ж ознайомлення з текстом статті навіює думку, що саме цього й бракує авторові публікацій про метод, як і багатьом іншим авторам.

Опосередкованим підтвердженням такого висновку може бути та обставина, що до наведеного визначення академік не сам додумався, а запозичив його (за власним зізнанням) в одного з тогочасних популярних в Україні європейських мудрагелів - Гадамера. А там здавна в пошані мода на такі-от куці дефініції, що безпідставно видаються авторами та, що ще гірше, сприймаються декотрими читачами за істинні. Приміром, Аристотель (за захопленим свідченням С. Кримського) вважав, що нібито «політика - це практична мудрість» (12). Інший філософ (здогадно, Ф. Шеллінг) буцімто твердив, що «архітектура - це «застигла» музика» і таке інше. Можливо, саме завдяки некритичному сприйняттю подібних визначень набули поширення такі неповні дефініції, як-от «мистецтво - це форма суспільної свідомості», "мистецтво - це засіб самовираження». Або й такі: «Культура це форма перебування адекватних цінностей, якими ми продовжуємо жити...» (Кримський, 2001). Не вдаючись у запізнілу полеміку з авторами цих та подібних 
афоризмів (їх не злічити), навіть на віру приймаючи їх за істини, задаймося питанням: «А що дають нам такі, з дозволу сказати, "дефінішки»? Чим конкретно збагачують наші знання про згадувані у них явища?».

\section{Постановка проблеми}

Поза сумнівом, навіть після тривалих роздумів відповідь буде вельми стриманою, коли не цілковито негативною. I на те є ціла низка причин. Починаючи з того, що подібні умовиводи зроблені внаслідок брутальних логічних огріхів (порушення правила визначення понять через вказівку на родову його приналежність та зазначення видових особливостей), що залишає непроясненим зміст означуваного поняття. У нашому конкретному випадку, між іншим, не увиразнено, про який власне метод іде мова, адже цим словом означено різні за сутністю, хоч у дечому й подібні, явища. Наприклад, системний, індуктивний, дедуктивний і метод перенесення (метафора, трансдукція), методи аналізу та синтезу, порівняльний метод тощо - у пізнавальній діяльності людей. Свої, принципово відмінні методи у галузі виробництва: метод безперервної розливки сталі - у металургії, метод комп'ютерного проектування - в архітектурі та будівництві, конвеєрний метод у машинобудуванні і т. ін., метод переконання - у царині виховання... Подібно і в мистецькій сфері належить розрізняти пізнавальний (так званий художній) метод (осягнення дійсності мистецькими засобами) і творчий (виробничий).

Логічне «сплутування» останніх двох понять та означуваних ними явищ далося взнаки й історично: зокрема при інтерпретаціях так званого «методу соціалістичного реалізму», який часто-густо іменували "художнім», хоча при цьому мали на оці саме творчий (тобто виробничий) аспект. Бо художній метод це різні форми пізнання дійсності мистецькими засобами.

Отож, для з'ясування сутності (природи) методу як соціокультурного феномена необхідно насамперед роздивитися походження цього слова та означуваного ним явища. Як ото полюбляли говорити древні: «Ab ovo usque ad mala»' .

Нагадаємо: наше слово метод походить від грецького $\mu \varepsilon \theta o \delta o \varsigma$, утвореного поєднанням двох слів: $\mu \varepsilon \theta о$ [мето] - після того як, потім та обо [одос] - дорога, шлях (місце, по якому ходять, та й сама дія, тобто засіб, спосіб досягнення чогось). Первісно це слово означало «слідом за чимось» (тобто проторованою дорогою).

Згадайте лишень ваші початково мученицькі спроби впоратися з кубиком Рубіка і подумайте, чому надалі стало так просто виконати необхідні маніпуляції? Саме так: ви йшли вже прокладеним, добре освоєним шляхом, тобто ви оволоділи методом вирішення цього хитромудрого завдання. Можна сказати про це поіншому: ви осягнули засадничі принципи побудови цієї іграшки, тобто оволоділи логікою побудови головоломки, яка містить у собі алгоритм ії розв'язання.

Переходячи до питання про метод мистецької творчості, ми можемо припустити, що у своїй «субстанціональній сутності» він являє собою осягнуту, осмислену

\footnotetext{
${ }^{1}$ Від яйця до фруктів - лат. приказка, що відображає звичне меню сніданку, тобто від початку до кінця.
} 
Вісник Київського національного університету культури і мистецтв.

Серія: Сценічне мистецтво

логіку творення (творчого процесу, творчості). Оскільки ж творчий процес взагалі, зокрема й мистецький, включає в себе різноаспектні складові (пізнавальні, психологічні, ідеологічні, виробничо-технічні), творчий метод як «логіка» цього процесу неминуче повинен мати відбитки цих складових.

Цим і зумовлений вибір теми дослідження: «Технологічні, гносеологічні, психологічні та ідеологічні складові «грані» творчого методу (поетики)».

Мета статті - з'ясувати роль та значення гносеології (логіки пізнання) у творчому мистецькому процесі (поетики, творчого методу).

\section{1. Методи образного відтворення дійсності}

Цікавий і повчальний приклад того, як усвідомлення логіки створення мистецьких предметів стає методом творчості, залишив С. Ейзенштейн. Розповідаючи про своє перебування в США (стаття «Монтаж-1938»), він пригадує, що спочатку йому було важко орієнтуватися в Нью-Йорку: «Аби зарадити цьому, доводилось встановлювати у пам'яті набір предметів для тієї чи іншої вулиці, набір предметів, що виникали в свідомості у відповідь на сигнал «сорок друга» на відміну від сигналу «сорок п'ята». Набирались у пам'яті, - веде далі Ейзенштейн, - театри, кіно, магазини, характерні будинки і так далі для кожної вулиці, яку належало запам'ятати. Таке запам'ятовування йшло виразними етапами. Таких етапів можна відзначити два: у першому з них на словесне означення «forty second street» («сорок друга вулиця») пам'ять з великими труднощами у відповідь перераховувала весь ланцюг елементів, характерних для цієї вулиці, але справжнього відчуття цієї вулиці не виходило, тому що окремі елементи цієї вулиці ще не склалися в єдиний образ. І тільки на другому етапі всі ці елементи стали сплавлятися в єдиний виникаючий образ: при назві «номера» вулиці також поставав цілий рій окремих ії елементів, але не як ланцюг, а як щось єдине ціле, як цілісний вигляд вулиці, як цілісний їі образ» (Эйзенштейн, 1966, с.258).

Це самоспостереження видатного митця щодо механізму становлення образів світу у свідомості людини цікаво та повчально зіставити з аналогічним судженням видатного теоретика мистецтва І. Канта. «Кожний бачив, - відзначав філософ, - тисячу дорослих чоловіків. Однак, коли хоче судити про їх нормальний зріст порівняльно, то уява (на наш погляд) накладає велику кількість образів (можливо, всю цю тисячу) один на одного. Хай буде дозволено мені застосувати тут аналогію оптичного зображення на площині, де поєднуються численні елементи, і в тих межах, де місце висвітлюється найсильніше накладеним світлом, там стає помітною середня величина. Це і є фігура прекрасного чоловіка» (Кант, 1898, с.82).

I. Кант стверджував, що можна те ж саме одержати й механічним шляхом, якщо всю тисячу розмірів по їх висоті та ширині скласти разом і одержану суму поділити на тисячу. Але «уява робить те ж саме через динамічний ефект», що «виникає з багатократного впливу таких фігур на органи внутрішнього чуття... і тому негр за цих емпіричних умов з необхідності повинен мати іншу нормальну ідею про красу, ніж білий, китаєць - іншу, ніж європеєць» $(1898$, с.83). Як бачимо, в обох випадках зафіксований майже ідентичний процес становлення образу в уяві того, хто сприймає видимий світ. Але І. Кант був філософом, а не митцем, і його цікавили загальнотеоретичні закономірності цього психологічного механізму. До 
того ж він стояв на позиціях філософського ідеалізму, дотримувався переважно точки зору агностицизму, відтак вважав неможливим пізнання мистецтва взагалі, закономірностей художньої творчості зокрема. Через те він вважав неможливим навіть існування того, що ми називаємо творчим методом. «Є, - твердив Кант, два види поєднання думок у викладі, із яких один називається манерою (modus aestheticus), а другий - методом (modus logicus); ці два способи (!) відрізняються один від одного тим, що перший не має ніякої іншої міри, окрім відчуття єдності в уяві, а другий наслідує принципи; для красних мистецтв має значення через те тільки перший» (1898, с.192).

«Все, що робив Ньютон, він усвідомлював, Гомер - ні», - твердить філософ на доказ істинності своєї думки.

Звичайно ж, полеміка з І. Кантом видається дещо запізнілою та й недоречною тут, тому обмежимося лише двома побіжними зауваженнями. По-перше, Гомер міг усвідомлювати те, що і як робить, такою ж мірою, як і Ньютон, і навпаки: вони могли усвідомлювати принципи (логіку) власної творчості, а не всезагальні принципи творчості; а, по-друге, таке заперечення можливості пізнання логіки творчого процесу є негативним доказом (принаймні свідченням) того, що під творчим методом І. Кант розумів саме усвідомлювану, пізнану логіку творчості.

С. Ейзенштейн був передусім митцем, він вірив у можливість та вірогідність пізнання зовнішнього світу так само, як і в можливість пізнання мистецтва та законів його творення. Його насамперед цікавили практично-творчі висновки з виявленого психологічного явища, івін препарує його для того, аби скористатися закономірністю стихійного становлення образів у свідомості людини, тобто свідомо застосувати її у власній творчій практиці.

Простежимо за ходом думки С. Ейзенштейна. «В обох випадках, - пише він, йдеться про процес запам'ятовування чи про процес сприйняття художнього твору - залишається правильною закономірність того, що одиничне увіходить у свідомість і почуття через ціле і ціле - через образ» (1966, с.258). А якщо це так, якщо сприйняття мистецьких творів є процесом становлення образів у почуттях та свідомості глядача, аналогічним до процесу становлення таких же образів у повсякденному житті людей, зокрема й митців, то завдання творця зводиться до того, робить висновок С. Ейзенштейн, аби «примусити» глядача пройти той шлях, що його пройшов сам художник...

Однак, що це за шлях, який він?

Інерція нашого мислення підказує: це має бути такий точнісінько шлях, яким пройшов митець, коли у нього складався певний образ того, що він сприймав (бачив, чув тощо). Але ні! С. Ейзенштейн мовить про щось трохи інше: «Глядача примушують пройти той же творчий шлях, яким пройшов автор, створюючи образ!» (1966, с.258).

На думку С. Ейзенштейна: «У запам'ятовуванні, - продовжує він намічену паралель між життям та мистецтвом, - $є$ два і дуже важливих етапи: перший це становлення образу, а другий - результат цього становлення і значення його для запам'ятовування. При цьому для пам'яті важливо приділяти якомога менше уваги першому етапові і якнайскоріше, перейшовши через становлення, 
Вісник Київського національного університету культури і мистецтв.

Серія: Сценічне мистецтво

$2019 \cdot 2(1) \cdot c .27-41$

досягнути результату. Така життєва практика на відміну від практики мистецтва. Бо, переходячи звідси до сфери мистецтва, ми бачимо виразне зміщення акценту. Природно прагнучи результату, мистецтво, однак, всю витонченість своїх методів спрямовує на процес» (1966, с.267).

Звідси С. Ейзенштейн робить принциповий теоретико-методологічний висновок: «У методі створення образів мистецький твір повинен відтворювати той процес, за допомогою якого у самому житті складаються нові образи у свідомості та почуттях людини» (1966, с.259). І далі на величезному фактичному матеріалі з історії мистецтв та своєї власної творчої практики переконливо доводить правильність цього положення.

Отже, перед нами - формула творчого методу. І тим паче цікава й знаменна, що не просто свідчить про своє походження з логіки пізнання, але навіть сформульована в підсумкуцілеспрямованого усвідомлення цієї логіки, її осмисленого використання саме як логіки, способу, методу побудови художніх творів.

При всій незаперечній правильності вищенаведеної формули закономірності становлення образів у сприйнятті митця та майбутнього споживача його творів вона має по суті нескінченне число значень.

Почати з того, що навіть при тотожності об'єкта сприйняття (наприклад, тих же вулиць) свідомість різних людей фіксує різні елементи, що складаються потім в образи, які уже тільки через одне це можуть бути відмінними одні від одних; потім - вибір засобів для реалізації, втілення цього образу (живопис, графіка, фотографія) диктують відмінні техніки та технології побудови образу, які, отже, позначаться на кінцевому результаті... А коли до цього додати психологічні настанови автора та майбутнього глядача, їхню ідеологічну націленість, що може бути не просто відмінною, а й діаметрально протилежною за спрямуванням?

Багатоманітність творчих методів (поетик) навіть у межах того самого, здавалось би, мистецтва має своєю передумовою саме цю обставину.

Іншими словами, саме тут криються зерна не тільки різноманітних стилів та манер, часом навіть досить чудернацьких, але й художніх течій, напрямів та шкіл. Подібно до того, як переважне використання тієї чи іншої технічно-технологічної особливості процесу творчості надає особливої своєрідності творчій практиці митця (індивідуальні манера, почерк, стиль тощо), так схильність митців до використання певних особливостей (сторін, граней) художнього пізнання сприяє їх об'єднанню в певні школи, течії, напрями.

Цілком зрозуміле прагнення митців осмислити свій метод творчості-художньо переконливо довести його переваги та науково-теоретично його обґрунтувати. В останньому митцям намагаються допомогти дипломовані «теоретики від мистецтва», особливо філософи (сиріч естетики), і в результаті з'являються цілі художньо-естетичні системи, більш чи менш логічно обґрунтовані та художньою практикою підкріплені.

Цілком природно також, що прихильники (тим більш винахідники) тих чи тих творчих методів переконані в їх продуктивності й мало не винятковій доцільності, а тому відстоюють свої позиції всіма доступними, прийнятними, а часом і неприйнятними в суспільстві засобами. Славнозвісний Мікеланджело 
Буонарроті, як відомо, особливо пишався тим, що ніс його набув горбатого профілю в результаті принципової художньо-естетичної дискусії, в якій він вважав себе переможцем.

Звідси безліч художніх течій та напрямів, запекла боротьба між ними, сповнена колізій та перипетій, часом драматичних...

\section{2. Методи перетворення образу дійсності}

На прикладі, наведеному й проаналізованому С. Ейзенштейном, ми можемо спостерегти, як із логіки образного пізнання (відображення світу) кристалізується цілком певна технологія, тобто методологія, творчості. Вона виходить, поперше, з того, що художній твір є образом, адекватним реальній дійсності: картина із зображенням вулиці у Нью-Йорку (той образ цієї вулиці, що склався в уяві художника). Правдиво і досить точно відображає (віддзеркалює) реальний (предметний) вигляд цієї вулиці. По-друге, припускається, що сприйняття художнього твору глядачем відбувається за тими ж закономірностями, що й сприйняття митцем реальної дійсності. Нарешті, мовчазно приймається за істину, що той образ, який «складається у самому житті» в уяві митця, є вже водночас і прообразом майбутнього твору.

Хто хоч трохи знайомий з живописом, знає, що значення співвідношення «художній твір» - «об'єкт зображення» (чи то вулиця, чи квітка, чи навіть людська персона) і за змістом, і за формою коливається в межах від безумовної адекватності до абсолютної невідповідності. Художній твір буває або майже рабською копією реального предмета, або чимось таким, що взагалі не має аналогій у довкіллі. Так само й в інших аспектах.

Особливо, що стосується своєрідності сприйняття митцем реальності, у тому числі й художніх творів. Якщо у звичайного глядача в результаті описаного С. Ейзенштейном процесу сприйняття чи то предмета природного походження, чи мистецького твору цей процес в уявному образі, так би мовити, згасає, затухає, то у митця все відбувається інакше: з цього, власне, й починається творчий процес. Сприйняті враження художник, на відміну від звичайного глядача, сказати б, переплавляє в горнилі власної фантазії і з цього вже переплаву виробляє (спочатку, ясна річ, лише в уяві) не лише образ того, що він пізнав у дійсності, але й образ того, що потім, у результаті предметної реалізації (втілення) в процесі творчої праці стане художнім твором. Той самий ідеальний результат праці, який уже на самому початку трудового процесу існує в голові творця як мета.

Пишномовно висловлюючись, митець тут уподібнюється бджолі: він не просто споживає нектар вражень, але й виробляє з них, так би мовити, краплини художнього меду.

Так от, подібно до того, як образ, що склався у пам'яті митця в результаті спостереження нимпредметів реальності,неєабсолютною копієюспостережених ним об'єктів, так і образ, уже створений митцем (втілений у художньому творі), не тотожний своєму ідеальному прообразу, бо процес реалізації прообразу художнього твору, як і процес формування внутрішнього образу довколишніх речей, відбувається в умовах певних збагачень та втрат. 
Але найважливіше навіть не це. Головне те, що відрізняє прообраз майбутнього твору від образу, який склався в уяві (пам'яті) художника під впливом сприйняття дійсності. Тобто ті зміни, які відбуваються у творчій уяві митця, у горнилі його уяви із враженнями, які він почерпнув з об'єктивної навколишньої чи й суб'єктивної внутрішньої реальності, на шляху перетворення їх у мистецький задум - прообраз майбутнього твору. Адже саме цей шляхє тим, що його пройшов митець, створюючи образ; саме його логіка, на думку С. Ейзенштейна, має стати методом творчості.

Саме цей процес І. Кант вважав принципово непізнаванним, відносячи його до природжених здібностей (генія). Саме перед цим процесом творення образів, як надзвичайно важливим і незвичайно важким для розуміння, так би мовити, шанобливо знімав капелюха Г. Гегель.

I найбільше вражала їх при цьому не так здатність творчої уяви до точного відображення сприйнятого, як її нестримний потяг до витворення небаченого, нечуваного, незнаного. «Уява (як продуктивна здатність пізнання) дуже сильна у створенні ніби другої природи із матеріалу, який надає йому перша, захоплювався Кант. - Ми бавимося нею, де досвід нам видається надто пересічним; ми переробляємо цей досвід, щоправда, не завжди за аналогічними досвіду законами, але й за тими принципами, які перебувають вище досвіду, у розумі (і які для нас так само природні, як і ті, за якими глузд сприймає емпіричну природу); але при цьому ми відчуваємо свободу і від законів асоціації (що властиво емпіричному застосуванню цієї здатності), так що тут ми, хоча й отримуємо від природи матеріал, але цей матеріал ми можемо переробити для чогось цілковито іншого - саме для того, що стоїть уже вище природи» (Кант, 1898, с. 259). На думку І. Канта, за допомогою уяви, що «слідами розуму прагне досягти все більшого та більшого», митець намагається «у всій повноті дати чуттєвий образ того, для чого у природі нема прикладу» (Кант, 1898, с.259).

«Джерелом художніх творів, - вважав Гегель, - $є$ вільна діяльність фантазії, яка у створенні своїх уявних образів ще вільніша, ніж сама природа» $(1968$, с.5). Перед цією продуктивною потужністю, перед цим розмаїтим багатством, за словами Г. Гегеля, думка «ніби втрачає мужність і готова відмовитися від своїх претензій повністю з'ясувати собі ці образи фантазії, винести свій вирок їм і підвести їх під всезагальні формули» (1968, с.5). У цьому судженні - не лише критика агностицизму І. Канта, але й співчуття йому, визнання справжніх труднощів осягнення процесу творчості, його закономірностей.

Тимчасом самецеймоментупроцесітворчостібувізалишаєтьсянайважливішим як для формування в митця творчого методу, так і для прояснення природи мистецтва взагалі. Не випадково саме звідси беруть початок найрізноманітніші (від романтизму до сюрреалізму та концептуалізму) творчі методи та відповідні концепції мистецтва. «Коли людині знадобилося імітувати ходу, вона створила колесо, зовсім неподібне до ноги». Ці слова не випадково приписують Аполлінеру. «Першочергове завдання митця - підмінювати природу і протестувати проти неї», - повчав художників Ш. Бодлер. «За допомогою мистецтва ми виражаємо наше уявлення про те, що не є природою», - заявляв П. Пікассо (Владимирский ред., 1957, с.10). 
Отже, перед нами - так само формулювання цілком певної поетики, методів творчості, за якими, подібно як і у випадку, описаному С. Ейзенштейном, належить примусити глядача (читача, слухача тощо) пройти у своїй уяві той шлях, яким пройшов, створюючи образ, сам митець. Відмінність, однак, полягає в самому цьому шляху. С. Ейзенштейн, мовлячи про нього, напевне, мав на увазі, що прообраз майбутнього твору (ідеальний образ) є адекватним, принаймні істотно не відрізняється від того образу, що склався в митця під час пізнання дійсності. У щойно наведених судженнях ідеться якраз про зовсім протилежне.

Прихильників творчого методу, які так чи інакше солідарні з баченням С. Ейзенштейна, віддавна прийнято було називати реалістами, а відповідну концепцію мистецтва - реалізмом; адептів іншого погляду - відносити до різних течій (напрямів, шкіл тощо), нібито нереалізму (романтизму, сюрреалізму, експресіонізму, імпресіонізму, концептуалізму тощо). Проте реальна картина виявляється, зрештою, набагато складніша та й цікавіша.

\section{3. Реалізм - нереалізм в історії мистецтва}

Що б там не говорили прихильники «розмитих берегів» і «невизначених критеріїв», як би не намагалися то розширити, то звузити межі реалізму, уся дотеперішня історія мистецтва, власне філософська та політична його історія, пройшла в запеклій боротьбі прихильників цих двох основних напрямів.

Розглянемо найбільш виразні прояви цієї боротьби.

Філософ Аристотель своїм визначенням мистецтва поезії просто констатує факт існування двох родів мистецтва: наслідувальних (до яких відносить усі мусикійські, тобто пов'язані з музами (від гр. Моvба муза - богиня-покровителька одного з мистецтв) та технічних. Платон відверто висловлює свої симпатії саме наслідувальним мистецтвам. Навіть «мусичні мистецтва» він визнавав тільки як «зображальні і відтворюючі», а «правильність² у цих мистецтвах зумовлена не насолодою, а взагалі тотожністю відтворення з оригіналом щодо величини та якості» (Асмус ред., 1937, с. 115). Усе, що робилося в мистецтві не у відповідності до оригіналу, до істини, Платон вважав негідним. «Ніколи музи не змішали б голоси звірів, людей, звуки знарядь і всілякий шум з метою відтворити щонебудь єдине. Людські ж поети сильно сплутують і нерозумно змішують усе це...» (Асмус ред., 1937, с. 115). Саме тоді, певно, зароджувалася інструментальна музика, і Платону вона теж дуже не подобалася, зокрема й через те, що не мала свого оригіналу, який би відтворювала. Ми поки що залишаємо осторонь інші, ідеологічні та політичні мотиви естетичних уподобань Платона (про них піде мова далі), але сам факт його прихильності до поетики відтворення, що цілком плине в руслі реалістичної, виходячи з наведених його суджень, здається безсумнівним.

Ще заповзятішим борцем за правдивість мистецтва був Марк Вітрувій Полліон, римський архітектор і теоретик мистецтва, вчений з надзвичайно глибокими та різнобічними знаннями. «Твором живопису, - зазначав Вітрувій, $€$ зображення того, що є, або того, що може бути, як наприклад, зображення

\footnotetext{
2 Тобто те, що робить їх мистецтвами, - С. Б.
} 
людини, будинку, корабля та інших речей, тобто певних конкретних тіл, з яких знімаються ніби моделі засобами зображального уподоблення» (1936, с.191-192). Марк Вітрувій простежує розвиток настінного живопису, в основі якого спочатку було наслідування, а потім штукатурні облицювання розписувалися «все більше зображеннями екстравагантного характеру, а не чіткими образами, запозиченими від конкретних явищ життя» $(1936$, с.192). Автор приходить до висновку, що «не слід схвалювати твори живопису, далекі від правдоподібності, і не слід через те тільки зразу давати про них позитивний відгук, що вони виконані витончено з боку мистецького виконання, оскільки їх сюжетні дані не витримують без натяжки критики та не мають розумних і реальних виправдань» (Витрувий, 1936, с.193).

Цікаво, що свої погляди Марк Вітрувій послідовно поширював і на архітектуру, яку теж вважав мистецтвом наслідувальним.

Історія, наскільки можна судити, не залишила для порівняння міркувань тих, хто вперто дотримувався іншої поетики, методу творчості, який призводив до відходу від зображення реальних явищ та предметів, взагалі наслідування природи. Зате наш час дає чимало для цього матеріалу. Кожний, хто взяв на озброєння один з методів творення не за образом і подобою того, що бачить чи чув, заповзято відстоюючи своє право на таку творчість, у міру своїх сил та здібностей якось виправдовує та пояснює його. У тій чи іншій формі такі погляди, варіюючи їх на всі лади, висловлювали й висловлюють, починаючи від романтиків і закінчуючи сюрреалістами.

Відчайдушну спробу загальнотеоретичного обґрунтування та політичного виправдання поетики, що сповідає мистецьке перетворення дійсності, взяв на себе Р. Гароді. Він вважав, що мистецтво $€$ «не копіюванням дійсності», а «чисто людською творчістю». Так, ніби чисто людська творчість не може включати й як один з елементів також копіювання дійсності. Однак ця думка за своїм пафосом продовжує еволюцію, яка викорінилася з часів романтизму: наростання сумнівів у тому, що реальність, зовнішня чи внутрішня природа, являє собою модель, яку належить відтворювати. Р. Гароді стверджував, що природа, звичайно, надає фарби, форми, зовнішній вигляд речам, створюючи їх як сировину. Художня ж творчість має своїм завданням, на його думку, не відтворення світу, а вираження прагнень людини (так, ніби прагнення людей не належать до реальної дійсності).

На одному полюсі, як бачимо з наведених прикладів, перебувають безумовні реалісти; завдання та можливості мистецтва вони вбачають у наслідуванні і тільки наслідуванні природи; на іншому - безоглядні творці небаченого, нечуваного, насамперед уявлюваного.

При цьому, так би мовити, філософський фон позицій досить пістрявий. Серед перших ми бачимо наївного матеріаліста Марка Вітрувія і далеко не наївного ідеаліста Платона; серед других - людину, що зараховувала себе до матеріалістів-діалектиків. Що ж до золотої середини, то й вона представлена ідеалістом-діалектиком (Г. Гегель) та непослідовним ідеалістом-агностиком (І. Кант). 
Це обриває звичні паралелі (реалізм - матеріалізм, нереалізм - ідеалізм) i, здається, взагалі заплутує філософські сліди поетики.

Справа в тому, що філософський вододіл у поетиці проходить, скажімо, не по ребру питання про відношення мислення до буття, а ніби впоперек нього - по лінії складних співвідношень суб'єктивного та об'єктивного в процесі пізнання взагалі та заплутаних координат між методами пізнання та методами творчості.

Подібну схему історичної динаміки концепцій мистецтва, певно, можна було б прийняти за відому натяжку, якби вона не відповідала й сьогоднішній дійсності. Адже й сьогодні ми є свідками того, як, з одного боку, безкрилий натуралізм, нудне й безвідрадне копіювання навколишньої дійсності видається за реалізм та ще й претендує на виняткове право на існування, а з іншого - абстракціонізм, сюрреалізм та інші види розриву будь-яких розумних зв'язків з навколишньою дійсністю видають себе за єдино можливе мистецтво.

Чи не останній «писк моди» на нереалізм - концепція так званого постдраматизму, яку автор - німецький вчений Ханс-Тис Леман (2013) подає як основний «вектор розвитку театру кінця XX - початку XXI століття. Основою європейського театру упродовж багатьох століть, справедливо вважає Х.-Т. Леман, була драма («смисл»). Сьогоднішні ж театральні вистави свідчать нібито про перехід до постдрами: «драма» або інший літературний текст», що використовується в театрі, стає лише елементом, матеріалом для постановки, але не його основоположним принципом. При цьому функція слова у перформативному ${ }^{3}$ театрі змінюється - акцент зміщується на тіло, а сценічна дія стає пластикоцентричною (Shevchenko, Shevchenko, and Salakhova, 2017).

Про ідеологічні та політичні передумови й наслідки цього явища мова піде в подальших наукових дослідженнях автора, присвячених аналізові методів та художніх стилів, що ж до філософського, гносеологічного коріння його, то воно полягає в метафізичному розриві складного й суперечливого процесу художнього творення, абсолютизації й протиставленні його певних рис чи стадій, етапів як ніби самостійних, незалежних, самодостатніх. Легко побачити, що теорія «копіювання» виростає з абсолютизації моменту адекватності сприйняття митцем навколишньої дійсності й нехтування здатністю та потребою митця в перетворенні цього первообразу в процесі вироблення прообразу майбутнього мистецького твору. Теорії на зразок тієї, що її відстоюють, виходять з абсолютизації саме моменту перетворення і нехтують відповідністю того, що творить митець, - первообразу навколишньої дійсності. І, незважаючи на їхні нібито революційні заяви про те, що мистецтво покликане буцімто не стільки розповідати про світ, скільки творити інший світ, незважаючи на претензію виставити на перший план революційну, перетворюючу функцію мистецтва,

\footnotetext{
${ }^{3}$ Перформатив - мовленнєвий акт. Перформативність як поняття міждисциплінарного походження, що позначає ситуацію збігу змісту з виявом. У разі перформативності зміст не розповідається, але відбувається його самоподача. Певне повідомлення (текст або дія) стає не просто висловлюванням про що-небудь, а й демонстрацією того, про що говорить це повідомлення.
} 
модерністська концепція, по суті, підриває основи цього покликання мистецтва. Бо бути зброєю в ідеологічній боротьбі мистецтво може тільки будучи засобом пізнання світу. Лише правдиво розкриваючи довколишній світ, тенденції та закономірності його розвитку, мистецтво спроможне виконати свою роль засобу ідейного (ідеологічного) перетворення світу відповідно до потреб людини.

\section{Наукова новизна}

Виходячи з такого розуміння мистецтва (мистецького творчого процесу), сутність поетики, яка з формального боку має вигляд деякої сукупності (системи) певних принципів та правил, автор у новому науково-дослідницькому ракурсі розглядає як логіку творчого процесу, у котрій своєрідними гранями постають (в різних видах мистецтва - різною мірою) гносеологічні, психологічні, ідеологічні та технологічні аспекти мистецького творчого процесу. У цій публікації поглиблено проаналізовано саме гносеологічний аспект поетики (творчого методу).

\section{Висновки}

Отже, наукове розуміння процесу художнього творення в уяві митця не має нічого спільного ні з однобічною вимогою копіювати навколишню дійсність, ні зі спробами порвати з нею будь-які зв'язки. Визнаючи дивовижну здатність людської свідомості до творення нових форм, науковий підхід далекий від намагання абсолютизувати її, а тим паче ставити цю здатність і продукти її реалізації над, вище або поза природою.

Людина сама є частиною та проявом природи, і отже, ніякий її витвір уже з огляду на це не може стояти нижче, вище чи десь збоку природи. Якщо відкинути звичайну метафоричність цього вислову, в основі якого лежить відмінність людини як мислячої і свідомої природи від усієї решти природи, то залишається суто філософський (тобто гносеологічний) аспект абсолютного протиставлення людини та природи як членів гносеологічного ряду. Усупереч твердженням різних ідеалістичних та агностичних філософій, за межами гносеологічного процесу людина та природа не протистоять одне одному абсолютно, а становлять суперечливу єдність усередині природи. Через це, що б не робила людина, як би вона не змінювала та перетворювала дане природою за формою, матеріалом, виглядом, фарбою тощо - усе це залишається в межах природи. I коли людина творить небачене чи нечуване, вона виходить тільки за межі власного конкретного досвіду, але аж ніяк не за межі природи.

Ясна річ, що там, де завдяки своїй здатності уявно (отже, необтяжено реальним матеріалом, простором і часом) оперувати з будь-якими предметами та явищами дійсності (в тому числі й уявної дійсності людської уяви, там, де (завдяки цій здатності) людина виходить за межі конкретного досвіду, суспільно-історичної практики, її підстерігають всілякі «несподіванки» і справжні труднощі. Та дають їм збити себе з пантелику й заплутати тільки люди, які втрачають чіткі зв'язки з практикою, досвідом, життям. Бо практика як критерій істини все ж у достатній 
мірі надійний орієнтир для того, хто не хоче збитися на манівці суб'єктивістських блукань.

Згідно з науково-матеріалістичною концепцією свідомість відтворює не тільки зовнішній вигляд явища, а і його сутність, при цьому в кінцевому підсумку творчої роботи свідомості виходить продукт, що поєднує в собі певну міру подібності та неподібності до первообразу. Художнє пізнання як пізнання перебігає саме цим шляхом, а як художнє відрізняється лише тим, що відбувається не у формі логічних понять, а у формі конкретно-чуттєвих образів. На цьому заснована матеріалістична концепція мистецтва як форми суспільної свідомості та розуміння творчого методу як логіки художнього пізнання. За таким розумінням всесвітньо-історична практика - практика реалістичного мистецтва, яке ніколи не було простою копією дійсності та ніколи не поривало з нею живих, відомих і видимих.

\section{СПИСОК ПОСИЛАНЬ}

Аристотель, 1958. Поэтика. Москва.

Асмус, В.Ф. ред., 1937. Античные мыслители об искусстве. Москва: Государственное издательство изобразительных искусств.

Витрувий, 1936. Десять книг об архитектуре [online]. Перевод Ф.А. Петровского. Москва: Издательство Всесоюзной Академии архитектуры. Т. 1. Доступно: <https://ru.wikipedia. org/wiki/Десять_книг_об_архитектуре> [Дата обращения 28 февраля 2019].

Владимирский, А. ред., 1957. Пикассо. Сборник статей о творчестве. Москва: Издательство иностранной литературы.

Гегель, Г.В., 1968. Эстетика. Москва: Искусство. Т. 1.

Дзюба, І., 2001. Метод - це насамперед розуміння. Літературна Україна, 25 січня.

Кант, И., 1898. Критика способности суждения. Санкт-Петербург.

Кримський, С.Б., 2001. У суперечці не народжується істина. День, 30 березня.

Леман, Х.-Т., 2013. Постдраматический театр. Москва: ABCdesign.

Эйзенштейн, С.М, 1966. Диккенс, Гриффит и мы. В: Избранные произведения. Москва: Искусство. Т. 5.

Shevchenko, A.R., Shevchenko, E.N., and Salakhova, A.R., 2017. Postdramatic Theatre of Director Christoph Marthaler. Journal of History Culture and Art Research, [online]. 6, 5. pp.173-178. doi: 10.7596/taksad.v6i5.1292 [Accessed 28 February 2019].

\section{REFERENCE}

Aristotel, 1958. Poetika [Poetics]. Moscow.

Asmus, V.F. ed., 1937. Antichnye mysliteli ob iskusstve [Antique thinkers of art]. Moscow: Gosudarstvennoe izdatelstvo izobrazitelnykh iskusstv.

Vitruvii, 1936. Desiat knig ob arkhitekture [Ten Books about Architecture] [online]. Translated from F.A. Petrovskogo. Moscow: Izdatelstvo Vsesoiuznoi Akademii arkhitektury. Vol.1. Available at: <https://ru.wikipedia.org/wiki/Desiat_knig_ob_arkhitekture> [Accessed 28 February 2019].

Vladimirskii, A. ed., 1957. Pikasso. Sbornik statei o tvorchestve [Picasso. Collection of articles about creativity]. Moscow: Izdatelstvo inostrannoi literatury.

Gegel, G.V., 1968. Estetika [Aesthetics]. Moscow: Iskusstvo. Vol. 1.

Dziuba, I., 2001. Metod - tse nasampered rozuminnia [The method is first of all understanding]. Literaturna Ukraina, 25 January. 
Kant, I., 1898. Kritika sposobnosti suzhdeniia [Judgment criticism of]. St. Petersburg.

Krymskyi, S.B., 2001. U superechtsi ne narodzhuietsia istyna [In the dispute, truth is not born]. Den, 30 March.

Leman, Kh.-T., 2013. Postdramaticheskii teatr [Post-Drama Theater]. Moscow: ABCdesign.

Eizenshtein, S.M, 1966. Dikkens, Griffit i my [Dickens, Griffith and we]. In: Izbrannye proizvedeniia. Moscow: Iskusstvo. Vol. 5.

Shevchenko, A.R., Shevchenko, E.N., and Salakhova, A.R., 2017. Post dramatic Theatre of Director Christoph Marthaler. Journal of History Culture and Art Research, [online] 6, 5. pp.173-178. doi: 10.7596/taksad.v6i5.1292 [Accessed 28 February 2019].

\section{ЛОГИКА ПОЗНАНИЯ («ГНОСЕОЛОГИЯ») КАК СОСТАВНАЯ ЧАСТЬ ТВОРЧЕСКОГО МЕТОДА}

\section{Сергей Безклубенко}

доктор философских наук, профессор, почетный академик Национальной академии искусств Украины; e-mail: bezklub@knukim.edu.ua; ORCID: 0000-0002-8709-7129

Киевский национальный университет культуры и искусств, Киев, Украина

\section{Аннотация}

Цель статьи - выяснение сущности поэтики (или, что то же самое, художественного творческого метода). Методология исследования базируется на принципе системности: автор придерживается концепции, согласно которой искусство как творческий процесс представляет собой определенную систему. Научная новизна. Будучи формой общественного сознания, способом самовыражения личности и средством утверждения определенных идей, искусство является вместе с тем одним из видов производства. Это производство специфическое (духовное), особенное среди духовных (художественное), но все же представляет собой то, которому присущи все фундаментальные черты производства вообще, в том числе (1) организационные, (2) экономические и (3) технологические. Относительно (1): искусство как производство художественных ценностей в своем историческом развитии проходит те же стадии общественной (коллективной) организации труда, что и производство вообще (в том числе и материальных благ). А именно: кооперация (иконописные, в общем малярные мастерские), мануфактура (театр), фабрика (кино), индустрия (телевидение). Относительно (2) - некоторые искусства (например, кинематограф) представляют собой самостоятельные отрасли производства, весьма эффективные в экономическом смысле. Относительно (3) - технология художественного производства, осмысленная в своей закономерности, определяет специфику искусства с его практически-производственной (ремесленной стороны). Выводы. Исходя из такого понимания искусства (художественного творческого процесса), сущность поэтики, формально имеющей вид системы определенных принципов и правил, автор рассматривает как логику творческого процесса, в которой своеобразными гранями возникают (в разных видах искусства - в разной степени) гносеологические, психологические, идеологические и технологические аспекты художественного творческого процесса. В данной публикации анализируется именно гносеологический аспект поэтики (творческого метода).

Ключевые слова: метод; творчество; искусство; технология; гносеология 


\section{LOGIC OF KNOWLEDGE ("GONOSEOLOGY") AS A CONSTITUENT OF THE CREATIVE METHOD}

\section{Serhii Bezklubenko}

Doctor of Philosophy, Professor, Honored Academician of the National Academy of Arts of Ukraine; e-mail: bezklub@knukim.edu.ua; ORCID: 0000-0002-8709-7129

Kyiv National University of Culture and Arts, Kyiv, Ukraine

\section{Abstract}

The purpose of the article is to find out the nature of poetics (or, the same, artistic creative method). The research methodology is based on the principle of systematic: the author adheres to the concept that art as a creative process represents a certain system. Scientific novelty. Being a form of social consciousness, a way of expressing a person and a means of establishing certain ideas, art is now one of the types of production. This production is specific (spiritual), especially among the spiritual (artistic), and yet it is one that has all its fundamental features in general, including (1) organizational, (2) economic and (3) technological. Regarding (1): art as the production of artistic values in its historical development is the same stages of social (collective) organization of labor, as production in general (including material goods). Namely: co-operation (icon-painting, general painting workshops), manufactory (theater), factory (film), industry (television). Concerning (2) - some arts (for example, cinema) represent independent branches of production, but very effective in the economic sense. As for (3) - art production technology, understood in its laws, determines the specificity of art with its almost-production (handicraft side). Conclusions. Proceeding from this understanding of art (artistic creative process), the essence of poetics, which formally looks like a certain set (system) of certain principles and rules, is considered by the author as the logic of the creative process, in which there are peculiar facets (in different forms of art and to varying degrees) epistemological, psychological, ideological and technological aspects of the artistic creative process. The epistemological aspect of poetics (the creative method) has been analyzed in this article.

Keywords: method; art; technology; gonoseology 